\title{
SPHINX NERII.
}

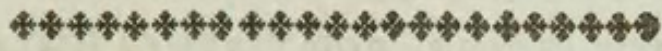

CHARACTER GENERICUS.

Antenna fubprifmaticæ, utroque fine attenuatæ. Lingua exferta (plerifque.)

$P$ alpi duo reflexi.

Ale deflexæ.

Lin. Syft. Nat. Gmel. p. 2371.

CHARACTER SPECIFICUS.

SPHINX alis fubangulatis viridibus ; fafciis variis pallidioribus faturatioribus flavefcentibufque.

$$
\text { Lin. Syf. Nat. p. } 79^{8} \text {. }
$$

Frifch. inf. 7.t. 3

Schaeff. ic. t. 100. f. 3. 4 .

ESp. pap. 2. t. 4 .

Cram. pap. 19. t. 244. $f$. D.

In pulcherrimis infectis quæ generat Europa locum fibi proculdubio vindicat animalculum in tabula depictum; in variis Germaniæ et Italiæ partibus repertum; præcipue vero in Italia. Larva ejus folia plantæ depafcitur quam Linnæus Nerium Oleandrum nominavit. 
Qui iconas hiftoriam naturalem explicantes probe callent, fentient mutuatos effe nos hanc noftram tabulam a figuris tantum non vivis et fpirantibus Domini Roefelii; quas fi exuperent, admodum defudaturos putemus hodiernos pictores. 


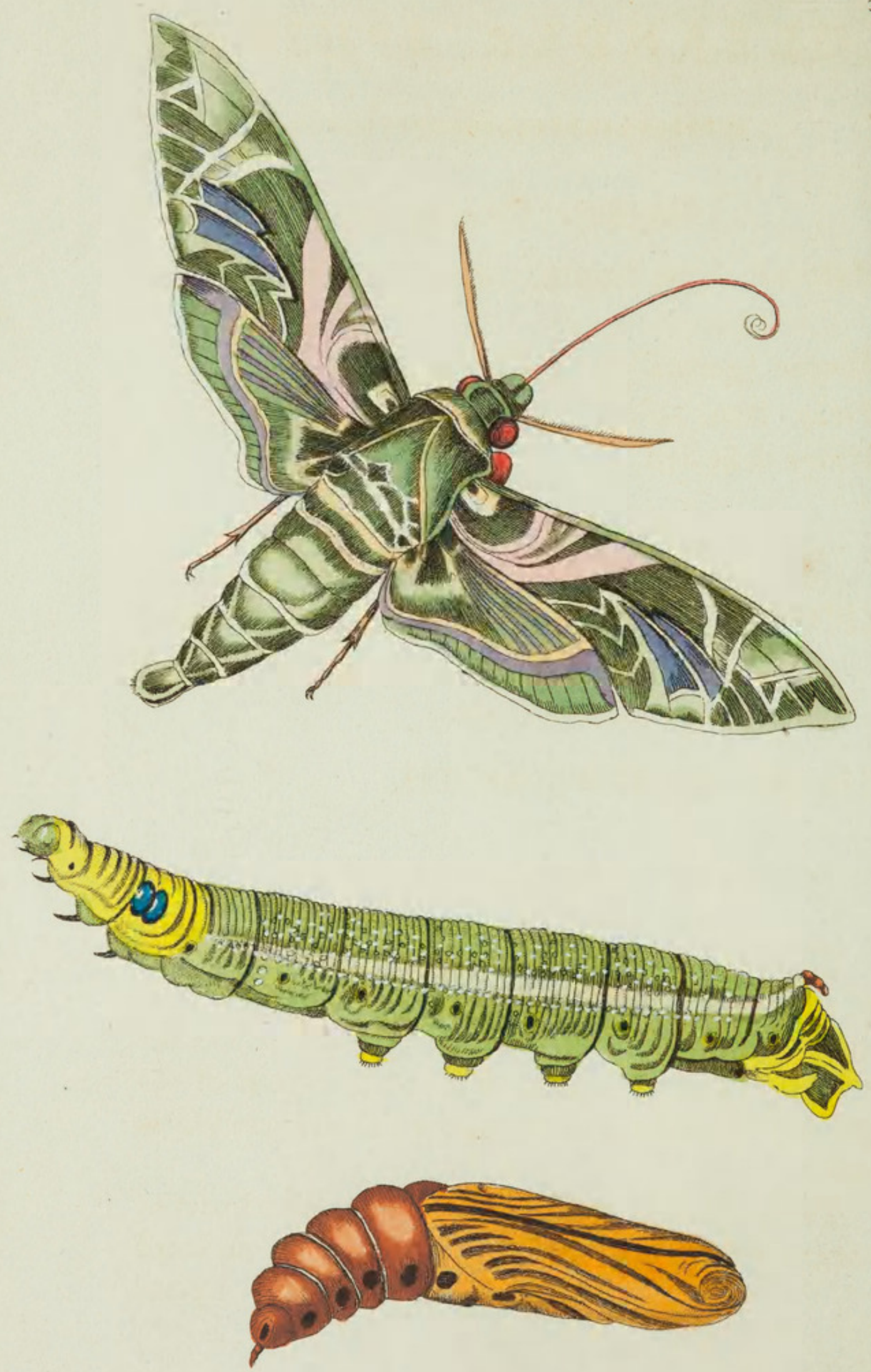

Ar. 


\section{OLEANDER SPHINX.}

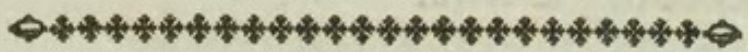

\section{GENERIC CHARACTER.}

Antenne fubprifmatic, attenuated at each extremity.

Tongue (generally) exferted.

Feelers two, reflex.

Wings deflected.

SPECIFIC CHARACTER, Ec.

SPHINX with fubangular green wings, varied with paler and deeper bands, and with a caft of yellowifh rofe-color.

The Oleander HAWK-MOTH.

This is unqueftionably one of the moft beautiful of the European infects. It is found in feveral parts of Italy and Germany, but more particularly in the former. The caterpillar feeds on the leaves of the Nerium Oleander of Linnæus or rofe-flowered Oleander.

Thofe who are converfant in the iconical part of natural hiftory will eafily perceive that the annexed plate 
plate is copied from the fpirited and beautiful figures of the admirable Roefel, whofe reprefentations, I believe, will not eafily be furpaffed by the attempts of any fucceeding artifts. 


\section{$2 \mathrm{BHL}$ Biodiversity Heritage Library}

Shaw, George. 1799. "The Oleander Sphinx, Sphinx neril. [PI. 372]." The Naturalist's Miscellany 10(CXIV), https://doi.org/10.5962/p.304554.

View This Item Online: https://www.biodiversitylibrary.org/item/276641

DOI: https://doi.org/10.5962/p.304554

Permalink: https://www.biodiversitylibrary.org/partpdf/304554

\section{Holding Institution}

Museums Victoria

\section{Sponsored by}

Atlas of Living Australia

\section{Copyright \& Reuse}

Copyright Status: Public domain. The BHL considers that this work is no longer under copyright protection.

This document was created from content at the Biodiversity Heritage Library, the world's largest open access digital library for biodiversity literature and archives. Visit BHL at https://www.biodiversitylibrary.org. 